\title{
METAPHORS ANALYSIS IN BRING ME THE HORIZON'S “AMO” ALBUM SELECTED SONG LYRICS
}

\author{
Moh. Nurman, Lidia Dindiana \\ mnurman@unisla.ac.id, lidiadindiana1@gmail.com \\ English Language Education Department, Faculty of Teacher Training and Education, Universitas Islam \\ Lamongan
}

\begin{abstract}
The aims of this research is to know the types of metaphors found in Bring Me The Horizon's "Amo" album selected song's lyrics and what is the intended meaning of the song 's lyrics. There are two research questions. They are: 1) what types of metaphors are found in Bring Me the Horizon's selected song lyrics? 2) What is the intended meaning of the song's lyrics? The reason behind this research was conduct is to get more knowledge about figurative language especially metaphor and how it works in the literary world. This research uses descriptive qualitative method in analyzing the lyrics. The result of this research shows six types of metaphors by Newmark. Those are dead, cliché, stock, recent, original metaphor and simile. Two out of their three songs of Bring Me the Horizon, that is Medicine and In the Dark use dead metaphor and simile the most. It is then concluded that the intended meanings of their three songs is to tell other people who everfelt belittled, have social issues or being looked down to keep going and not affected by those hurtful words. In other words, Bring Me the Horizon uses the function of figurative language especially metaphor to express their message and applied them into their works.
\end{abstract}

Keywords: Metaphor, meaning

\section{INTRODUCTION}

Figurative language is a figure of speech as a way of saying something other than their literal meaning of the words. Waluyo (1987: 83) stated that in expressing something in unusual way, authors like to use figurative language. It is deviates from the conventional work order and meaning to convey a complicated meaning, colorful writing, clarity, or comparison. Therefore figurative language is commonly uses by authors of literary artists to create their imaginative way of produce something.

Figurative language is a language that uses words out of their literal interpretation to achieve a more powerful and imaginary effect. Therefore figurative language is used in any form of literary works, such as poem, novels, and songs. Essentially, figurative language can help to convey, persuade, convince, impact someone using verbal or written message. It is also believed that using figurative 
language will help readers build up their imagination. The meaning of figurative language cannot be find in the dictionary just like the other vocabulary words that we usually use. According to Khodijah in her book (2010 : 2) defined that figurative language is categorized as the implied meaning because the words used in figurative language is not the real meaning but it is connotative meaning. When a writer uses literal language, then it is used to simply stating the facts or what the intended meaning is. It is different when they use figurative language. They want to engage their audience to provoke them by thinking more creatively and something more beyond the world. In this case, there have been many arguments at how many types of figurative language there are out there. However, authors of literary works tend to use these figurative language those are; simile, personification, symbol and metaphors. From those example metaphors appears as one of figurative languages that are use both in linguistic works and also in our daily conversation. According to Lakoff and Johnson on their book Metaphors We Live By (1980) explained that metaphors are pervasive in our ordinary everyday way of thinking, speaking, and acting. As a part of poetic and figurative language, authors have to make sure that the types of metaphor they used are clearly understood by readers.

Metaphor is a part of figurative language using an analogy or close comparison between two things that are not normally treated as if it had anything in common. Metaphor is common means of extending the uses and references of words. Arvius (2003:90) has said that metaphors are common in language use, and ordinarily it does not seem to require any particular effort to construct and understand them. According to Newmark (1988) he divided metaphor into six types of metaphors. Newmark (1988) classified six kinds of metaphors: As dead, cliché, stock, recent, 
original metaphor and simile. The first three, he considers as dead and the last two as live metaphors.

\section{Dead Metaphor}

It is the metaphor that loses its figurative and connotative meanings and is used like ordinary words; the image cannot be recognized by the speaker or listener. This category includes "Concepts of space and time, the main parts of the body, general ecological features and the main human activities" (Tajali, 2003: 108). Dead metaphor has three kinds. The first group is those which have a little metaphorical imagery. For instance, the word 'reflect' has a referential meaning of 'shining' and also, has a secondary meaning of 'superiority'. The second group is metonymies which come instead of objects and things, like, 'crown, worm, and fork'. This group is more used in technical texts. The third group is non-technical words like 'mouth and foot' used metaphorically when combined with other words. The example of metaphor are:
The arm of the chair, an arm of the heat and a matter of life and death.

\section{Cliché Metaphor}

Like dead metaphor, this kind of metaphor is overused so much that cannot convey any figurative meaning and "is used as a substitute for clear thought, often emotively, but without corresponding to the facts of the matter" (Newmark, 1988: 107). It is said that contrary to dead and stock metaphors, cliché metaphors have an indication that tell the reader the word or expression is not an ordinary one. The example of cliché metaphor: Explore all avenues, stick out a smile and a transparent lie.

\section{Stock Metaphor}

This is the one which deals with cultural elements and is conventional in each language. Newmark (1988: 108) said "A stock metaphor has certain emotional warmth-and which is not deadened by overuse". The example of stock metaphor are: Her life hangs on a thread, laugh in 
someone face, and she sees fear in my heart.

\section{Recent Metaphor}

This is a live metaphor, produced by coining or as Newmark (1988: 111) called "they are neologisms fashionable in the source language community". This kind is specific to each language and includes more colloquial and informal words. The example of this metaphor is: Park your carcass.

\section{Original Metaphor}

It is another kind of live metaphor arising from writer or speaker's personal and creative thoughts and ideologies, so it is not fixed in the language and is more new and fresh. Examples of this metaphor: I am close to the wet loneliness of grass and I hear the sound of gardens breathing.

\section{Simile}

The word simile is derived from the Latin word 'Simile', meaning 'resemblance and likenesses', technically it means the comparison of two objects with some similarities. Even children talking about their desires, use simile as a means of comparison. Simile is much less investigated than metaphor, although it occurs as frequently in discourse. According to Newmark on Fadae (1995 :88-94), similes has various functions. Unlike metaphors, similes require individuation of both source and target concepts, and an evaluation of what they have in common, but unlike literal comparisons, they are figurative, comparing things normally felt to be incomparable, typically using vivid or startling images to suggest unexpected connections between source and target. Example of simile is: She is as innocent as an angel.

It is common for metaphor to has the concept meaning and the literal ones. Usually known as denotative and connotative meanings. Arp and Johnson (2009: 674) described denotation as the actual meaning of what is written in 
dictionary, while on the other hand connotative is more like what is beyond expressed. In other words, it is need to understand the intended meaning of the song's lyrics in order to analyze works like song lyrics or poetry.

\section{Meaning}

Communication is a way of more than one people interact. In order to get a communication people uses two ways; verbal and non-verbal. As verbal, we use our mouth to speak or talking to each other.

Those followed as two ways of deliver our intention or mean. Every word has its own meaning and those also known as denotative and connotative meaning. Denotative is when people use the literal meaning, or straight from the original dictionary. It is uses to deliver their message in direct or literal way as possible. In simple words, they say or write what they want to say directly. While connotative on the other hand is way more complex than that. People do not say or write directly what they want to say to each other. They have the literal mean or something behind those words. In this research, the researcher analyzes what are the meanings behind two selected songs' lyrics. For more understanding both in denotative and connotative, it is very important to aware of what is their definition and concepts is.

Connotative meaning is created by the idea that has been connected to a certain meaning or emotional suggestions, which is related to that word (Parera, $2004: 132$ ). He also stated that denotative meanings and connotative meanings exist together and they are not easy to separate. It is on how the readers interpret the word and look for the meaning. In the end, it is all about perspective.

On the contrary, people always use denotative meaning when they really need to make others understand about what they really mean. It is because denotative language is way simpler to be told and easier to be understood. Parera (2004:97) explained that denotative language is an 
origin and a natural meaning which always comes out first and based on the context. Parera then also makes it clear that both denotative and connotative language will give certain emotion, character, and value. Those concluded, that denotative meaning is often to be found or written in a dictionary since readers needs to know about particular real or the intended meanings of some words. However, sometimes connotative meanings are also found and written in a dictionary.

Song is part of literary works. Song is the combination of melody, harmony and rhythm. According to Hornby (2000: 1281) said that song is a short piece of music with words that you sing. Song is like a short poem or bunch of poetic words that plays accompanied by music. To call it a song it does not have to be a five minutes long. Every song has lyrics. Lyric is a set of poetic words. It is means that every song has it story behind. The lyrics of the songs are like the key of the author's heart and mind. It is uses to express a person's personal feeling and thoughts. It tells their real life feeling and experience. Lyrics are set of words that make up a song. Lyric is written in order to give the audience an understanding message and deep meaning contained in a song.

In this study, the writer chose three songs from Bring Me the Horizon. Bring Me the Horizon is a British rock band formed in Sheffield 2004. Bring Me the Horizon is known for their way of creating popular songs around the world. "Amo" is their number sixth studio album which was released on $25^{\text {th }}$ January 2019. As already stated, there are three songs that writer has chosen, those are "Medicine", "In the Dark" and "Sugar Honey Ice \& Tea". Oliver Sykes, as the songwriter and vocalist states that most of Bring Me the Horizon's songs are talking about life issues, social problem, criticizing, and dealing with our relationship. Based on the previous explanation above, the writer has analyzed 
about the types of metaphors found in Bring Me the Horizon's selected song lyrics and what is the intended meanings behind their song lyrics.

The previous study which related eith this research is from Laurentius Jalu Waskitho Jati (2018), the student of Sanata Dharma University from Yogyakarta with the title "An Analysis of Metaphors Found in Bring Me the Horizon's Selected Song Lyrics". He only chooses two selected song based on Bring Me the Horizon's Album. Those are Drown and Throne while in this research focus to three songs. The author explains about the kinds of metaphors and which part of the song lyrics categorized as metaphors, while this study focuses on the intended meaning of the song lyrics.

\section{RESEARCH METHOD}

The writer uses research method to presents the methodology to analyze data. Therefore, the writer uses descriptive qualitative method in order to describe the data and also to get an accurate and factual result.

As already stated that this research uses descriptive qualitative method because the sources of this study are from written words which already being observed to detail in order to understand the meaning implied in the document or the object. The aim of descriptive qualitative method is to describe a place, fact and characteristic of something systematically, factually and accurately. The analyses in qualitative research concern in understanding the result of found data rather than calculate the result of found data. (Moloeng, 2009: 3). The aim of descriptive qualitative method is to describe a place, fact and characteristic of population systematically and accurately. Descriptive qualitative method employs technique of seeking, collecting and analyzing data

The writer uses two kinds for getting the data, they are: Primary Data Source and Secondary Data. The primary 
data source of this research is the song lyrics by Bring Me the Horizon.

Besides the primary data source, the writer also uses the other data sources or known as secondary source. In this case, the secondary data source can help the researcher to conduct and create the content of this thesis well. It can also become as references for someone who willingly to do a research about literature. The secondary data sources are acquired of journals, ebooks, and internet research to get some opinion, ideas and mainly theories from experts and their related with this research.

The writer analyzes Bring Me the Horizon's songs to collect the data which related with this research. For collecting the data, the writer through as these steps as follows:

a. Listening to the songs of Bring Me the Horizon of their $6^{\text {th }}$ album entitled "Amo". Those songs are Medicine, In the Dark and Sugar Honey Ice \& Tea. The writer uses AL Song application b. Reading the lyrics of "Amo" album in online website. The writer uses online websites www. metrolyrics.com

c. Underlining the words in order to finding out the types of metaphors which is uses in the lyrics of the songs.

d. Classifying certain lyrics that included in the associative meaning (intended meaning) using Meriam-Wesbter dictionary

e. Tabulating the categorized words into the table

\section{FINDINGS AND DISCUSSION}

The writer has analyzed and discussed about types of metaphor found on three selected song lyrics of "Amo" album and its meaning. The writer found six types of metaphor. Those are dead, cliché, stock, recent, original metaphor and simile. Here is the detail information about the types of metaphor found in the three selected song's lyrics; Medicine, In The Dark and Sugar Honey Ice \& Tea. Another information that 
will be find is the intended meaning or what is the author's message behind the songs' lyrics.

\section{Finding 1. Metaphor List of Medicine}

\section{Song}

There are five types of metaphors that found by the writer. Those are dead metaphors, cliché metaphors, stock metaphor, recent metaphor and simile. The first metaphors are already found in the first line of the song. The line sounds "Some people are a lot like clouds you know. 'Cause life's so much brighter when they go". As the writer has already searched about the theory of metaphor, it is safe to say that metaphor comes as a concept and have two terms considered called a metaphorical meaning.

In the first line, the concept of metaphors appears in the terms clouds and brighter. It is surely known that both terms do not represent their literal meaning in the song. The term clouds have literal meaning as a noun or an object floating in the sky.
When is followed by the term brighter, both terms might be similar to each other. But while take a wide look and see the full line, it is surely have different meanings. The word clouds here have the same meaning as people surrounding us. Those people aren't the best one for us. And then followed by the word brighter which has a connotatively meaning to let go or to set free them in order for us to get a live free or toxicity life. Because they will only bring sorrow and pain for us.

Then the terms "Couldn't see the thunder for the storm" which is classified as original metaphor. The word thunder here represent as some warning of what next is coming in their life and it is not good. Just like when hearing thunder when the rain or storm is happen. Then the term storm here illustrates as the horrible things that will come in his life. It is definitely different with the literal meaning of what those words actually are.

\section{Intended Meaning in Medicine Song}


Before analyze further into connotatively meaning, first thing first is to should focus on the tile of the song. The term "Medicine" is such a common word for this modern world. The literal meaning itself is more familiar in the health care world. It is a substance which is use to healing people from being in pain. That is what people usually think first when we read or hear about "Medicine" without caring to know the metaphor behind it. After take a closer look it will change the entire song differently.

While take a look at the words that recognized as metaphor, it is safe to say that the author of the song, Oliver Sykes described the song for a revenge or counter attack. It is what people call "let the karma works in their own way". Those words are rained, medicine, swallowing and thunder. Through those four words it can be concludes that it is about being stepped on or have been in a worse situation that got him want to revenge his anger. Oliver
Sykes has explained that this song is when someone finally got the karma of what they did to others. They all in the end up getting treated back just like when they treated differently, being looked down, and the struggle of life issues. Oliver as a songwriter wants to say that although some people have been through that kind of situation, do not get loose hope and want give up of our life. It is all will pass away as times went by. It is clearly stated in this following chorus of the song in "Medicine":

\section{[Chorus]}

You need a taste of your own medicine

'Cause I'm sick to death of swallowing

Watch me take the wheel like you, not feel

$$
\text { like you }
$$

Act like nothing's real like you

So I'm sorry for this, it might sting a bit

From the words of the lyrics above, the term medicine here represent something that will come back for them 
who has been doing something horrible to others. While following the next lyrics, the word swallow here means as something that Oliver Sykes states as the warning sign or the announcement from the victim. He states that finally he will declare the revenge or the new feeling of hope to fight against it instead of being helpless or give up. Although there is a hint of how sorry he is to those people in the following lyric "So I'm sorry for this, it might sting a bit”.

It is the song that Oliver decided to turn his vocal singing technique into more cleans without having such screaming sound. Medicine is a song about the feeling of being pushed down. The term Medicine is quite popular and has nothing do with the negativity or such dark intentions. While many people assume that this song is mainly about someone who has such addiction towards drugs or in this case medicine, the other are assume that this song is about someone who has suffered through some 'crazy' time in their life and they need those kinds of medicine or their pills. But it is then proofed wrong by the lyrics of the song. Despite the absent of the heavy metal touch, Oliver made his song to something unordinary following the making of the music video. The video music of the song captured as someone with many people body planted on the head's object. Then the many people body swallowed by the head's object. Through this song Oliver wants to tells other people that there is always time when everything come back at their belong place and there is always a consequences of everything we do.

\section{Finding 2. Metaphor List of In The}

\section{Dark Song}

Based on the finding 2, it is concluded that there three types of metaphors by Newmark were found in "In The Dark". Those are original, dead, and recent metaphor. The original metaphor is from the third lines of the song lyrics. The word $d u g$ is such a common words in our daily life. It is known the past participle of 
the word dig which has a meaning to remove. On the other hand while if it combines with the word cave it does changes the meaning in whole new level connotatively.

The second one is dead metaphor. In the lyrics of "In The Dark" there are two words that classified as dead metaphor. Those are black hole and bright. As already knew that black hole is an outer space region with no particles or even the slightest light, or in other words; dead end. While bright here has a meaning as something positive. It could be a person or emotion.

The last one is recent metaphor which could be found in the lines: "It's not his world you turned inside out" and “Guess my fairytale has a few plot holes". Given those two sentences it can be seen that the choice of words is a little bit cliché. It is not an ordinary way to put words like that. We can take a look on the word fairytale for an example. It is know as such an amazing place with full of fantasies but in real life there is no such a place. So the concept of metaphor is showed with the following words after it. The word plot holes here means that the person who is previously living his life as in fairytale, is no longer anymore.

\section{Intended Meaning in the Dark Song}

Just like the previous song which the listeners or readers need to focus on the title, it is the same of this song. The title of this song "In the Dark" literally meaning is represents when the day gets dark after the sun went out, or when the light in a room being switched off then we see nothing than just a dark room. That is what many understand about the term "In the Dark" before focuses on the figurative meaning that will surely change the entire song meaning. Therefore the analysis of metaphor is uses for further explanation.

Those terms are blackhole and drove. The term black hole surely have metaphor concept. Both terms are definitely 
not interpreted as their literal meaning. The term black hole is known as some outer space region. Therefore it is such a possible thing for the author went to the outer space. Oliver Sykes explains that this song is about his personal love life. While looking at the entire sentence, it is sure far from the literal meaning. He implies the song as a way he is coping with the situation that has happened to him. The song itself tells about his relationship with his ex-wife who has been cheated on him. He states that he is being left in the dark, while not knowing what is happening behind his back, so out of curiosity he then decided to do a little actions in order to find the real reason as to why he was being left. Just like the older saying, that "A good marksman may miss" which has the same meaning as there is no such secret that could we bring until we die. Therefore he creates the lyric as "In the Dark", which we all can see in the chorus of the song:

\section{[Chorus]}

So don't swear to God, He never asked you
It's not His heart you drove a knife

$$
\text { through }
$$

It's not His world you turned inside out Not His tears still rolling down Jesus Christ, you're so damn cold Don't you know you've lost control? Forget about the things you think I know No secrets, you can't keep me In the dark, in the dark No secrets, you can't keep me In the dark, in the dark

Another term that could be found in the chorus is the term turned which categorized as cliché metaphor. From the literal meaning of the term, it is safe to say that it is a past tense of the word turn and has the meaning of to move or doing something using their own body or some medium. Oliver Sykes states that the meaning of those lines is the way his life is not the same as his previous life after the conflict. The conflict he has faced surely did change him whether mentally or physically. He states that although he has 
lost the relationship he has built with his wife, Oliver not once regret the decision he has chosen. In the Dark song is different idea with the previous one. While being interview on some Radio live in America, Oliver Sykes explained behind the making of this song. He tells the interviewer that this song inspired by his real life problems. Oliver has some relation with his ex-wife that has not going really well. He states that this song is about the feeling of being left out or not having any ideas about anything that happening around him. Although this song is sounds calmer and clear than Medicine, but looking at the entire lyrics it sure has changed many thought. It is somehow has dark meaning but on the other hand sounds very softer and easy listening.

\section{Finding 3. Metaphor List in Sugar}

\section{Honey Ice \& Tea Song}

There are six types of metaphors based on Newmark (1988) theory, there are three two of them that were found in "Sugar Honey Ice \& Tea" song lyrics. Those are dead, cliché and recent metaphors. The dead metaphor is classified as metaphorical imaginary. As already seen of the first line of the song, which is "Don't rock the boat don't calm the storm". The term rock and calm surely has different meaning of what the author intended.

The word "Rock" here means as a noun or an object. While take a closer look, it is also has some different meaning for example it could be identified as verb. Take a look in our daily life. As a human being people surely have listened to rock music at least once. It is for sure different with every person to experience this strange feeling or to have such a connection. But it can be concluded that at some point, certain people will felt such a strong connection. When one listened to such songs he would feel some kind of strong urge to do something beyond our behavior or being motivated. It is also the same concept with the word "rock" in the "Sugar Honey Ice \& Tea" song. It means as some action to provoke or 
doing something that against the rules but in a good way. Another word that classifies as dead metaphor are muscle.

The other kinds of metaphor that could be found is a cliché metaphor. It can be seen it in these following lines "cause it's got my head running 24/7" and "his pants are on fire". The line running 24/7 surely has a metaphorical meaning. When we try to understanding it literally, it means a physical activity. But when we try fully understanding the whole sentence, the meaning will be different. "Running" here means that when something or someone keeps bugging them every single day a whole week. While on the other hand, the word "fire" is connotatively mean as rage or madness. Giving those statements it is safe to say that the meaning of the whole sentence is to provoke someone to the point they'll end up exploded or lose control

Intended Meaning in Sugar Honey Ice \& Tea Song

Before analyze the meaning behind of the song, lets pay attention to the title of this song. The term is "Sugar Honey Ice \& Tea" which have the literal meaning as some foods people usually see in daily life. It is set of delicious foods that help us to calming human nerves after have a rough day. On the other hand, if take a look closely to the figurative meaning, it is surely has different meaning of what many has thought before.

There are only two terms of metaphor concept in this song. Those are found in the terms of rock and calm. Both terms surely did not represent their literal meaning in the song. Oliver Sykes created this song for his way to deal with his problems and life or social issues. He states that he has been through some problems that he faced with his closest people and the result was not that good. The terms rock here means as the situation he faced before the problems arise. He encourages for people who have been through the same situation to not act impulsively. Then there is the term calm, which has the literal meaning as stay still or being completely in 
control. Given the statements before, and try to see it with the title as a whole context, then it is safe to say that this song is the way he overcome the stress he have been through by letting out his anger. Those proofed on the title "Sugar Honey Ice \& Tea" which means as a swearing he aimed for his messed up life. It is for his friends, colleagues and closest people who he cannot re-build the connection again or he is done with everything, with everyone as can see in the chorus:

\author{
[Chorus] \\ Sugar, Honey, Ice and Tea \\ Sugar, Honey, Ice and Tea \\ (Everybody's full of \\ Sugar, Honey, Ice and Tea \\ Sugar, Honey, Ice and Tea
}

The first two terms are categorized as dead and cliché metaphor, on the other hand the terms sugar honey ice and tea is categorized as recent metaphor. Oliver stated that he is done with everything, with everyone. He also states that it is not his responsible as to why is everyone being such a jerk towards him. It is such a brilliant idea behind the story of this song.

With the title named after foods, that is "Sugar Honey Ice \& Tea" but this song is sounds and does have a darker meaning than the two previous songs. Oliver Sykes tells that this song is about the social issues he has dealt with his closest people, in his case are his friends, colleagues and his dealing with the problems by himself. He wants to tells people around the world or his fans in particular, to not bothering keeping up with someone toxicity. It is not your fault if someone once you called bestfriend and now it is not anymore because something bad happened between you too. In this song, he had said that he is trying to cope with his situation although he knew he could not make it better. It is not your fault if you tired of trying to be the better person and try to keep the remaining hope that you 
too will be in a good terms again. If it is feel

like you have enough time with their dirty way towards ourselves, then it is okay to let the anger out and express to them.

\section{CONCLUSION}

Based on the findings presented in the chapter IV, the writer finally comes with some conclusions as follows:

The writer found six types of metaphors by Newmark (1988) in three of Bring Me The Horizon's selected song lyrics. They are dead, cliché, stock, recent, original metaphor and simile. Based on Oliver Sykes' life experience and related theory by Newmark, Oliver mostly uses cliché metaphor and simile. Simile is the most use based on the selected songs lyrics of Bring Me The Horizon. The lyrics of Bring Me The Horizon's selected song lyrics contain figurative language, that is metaphor. As for the second research question, the intended meaning of those three selected songs; Medicine, In The
Dark, and Sugar Honey Ice and Tea is something common and similar to each other. It is such a normal thing and it can be seen in the daily life. Oliver, as the songwriter of Bring Me The Horizon wants to tell others who ever felt being pushed down or underestimated to keep going and ignored them because sometimes karma always waiting for them. In other words Oliver Sykes as a songwriter uses metaphor in creating his works in order that people understand his message.

\section{REFERENCES}

Arp, T. R., \& Johnson, G. (2009). Perrine'sLiterature (10 thed.): Structure, Sound, And Sense. Boston.Arvius,

Christina Alm. (2003).Figures of Speech. Sweden: Student litteratur. Arikunto, Suharsimi. (2010). Prosedur Penelitian: Suatu Pendekatan Praktik. Jakarta: PT Rineka Cipta.

Dian. Siti, K. (2010). The Figurative Language Of Nirvana's Song. Cirebon. SyeikhNurjati State InstitueFor Islamic Studies Cirebon.

Fadaee, Elahe.(2011). Journal of English and Literature Vol. 2(2), pp. 19-27, Academic Journal. 
Hornby, A. S. (2000). Oxford Advances Learner's Dictionary of Current English. Oxford University Press.

Jati, L. J. W. (2019). An Analysis of Metaphors Found in Bring Me The Horizon Selected Song Lyrcs. Sanata Dharma University.

Lakoff. G., \& Johnson, M. (1980). Metaphors We Live By. Chicago: University of Chicago Press.

Maftucha, U. 2018. An Analysis of Figurative Language Meaning Found on The Song Lyrics by Adele's "25" Album. UNISLA.
Moleong, L. J. (2009). Metodology Penelitian Kualitatif. Bandung: RemajaRosdakarya.

Newmark, P. (1988). Approaches To Translation. London: Prentice Hall International (UK) Ltd.

Parera, J.D. (2004). TeoriSemantic( $2^{\text {nd }}$ ed.). Jakarta: Erlangga.

Tajali, (2003). Journal of English and Literature Vol. 2(2), pp. 19-27, Academic Journal.

Waluyo, H.J .(1987). Teori Dan Apresiasi Puisi. Jakarta: Erlangga 